\title{
SUCCESSFUL USE OF FLAMELESS OXYFUEL IN STEEL REHEATING
}

\author{
1Joachim VON SCHEELE, ${ }^{2}$ Vladimir ZILKA \\ ${ }^{1}$ Linde Technology, Linde plc, Munich, Germany, EU, joachim.von.scheele@linde.com \\ ${ }^{2}$ Linde Gas a.s., Brno, Czech Republic, EU, vladimir.zilka@linde.com
}

https://doi.org/10.37904/metal.2020.3460

\begin{abstract}
Using oxyfuel combustion in steel reheating provides higher throughput and substantial fuel savings. Accordingly, oxyfuel has many benefits, but also some drawbacks like hot spots in furnaces and thermal NOx generation. However, by making the combustion "Flameless" by creating a 'volume combustion', these issues can be overcome, and additional advantages can be achieved. This paper describes different solutions, both fully flameless and semi flameless, which have been developed and implemented in steel reheating and annealing furnaces.

Over the past three decades, Linde has made more than 160 oxyfuel installations in all types of reheating furnaces, both batch and continuous, and for production of all different steel grades. Since 2003, focus has been on using Flameless Oxyfuel, hitherto resulting in 112 successful installations, 90 of these operating fully with $100 \%$ Flameless Oxyfuel. This paper describes results from these installations, which include fuel savings of up to $60 \%$, increased throughput by up to $50 \%$, substantial reductions of $\mathrm{CO}_{2}$ and $\mathrm{NOx}$ emissions, much improved temperature uniformity of the heated steel, reduction of scale losses by up to $50 \%$.

Cases with conversion from air-fuel to Flameless Oxyfuel will are described. These examples comprise installations in soaking pit furnaces, rotary hearth furnaces, roller hearth furnaces, and walking beam furnaces with up to $300 \mathrm{t} / \mathrm{h}$ nominal capacity, and for production of carbon steel, engineering steel, and stainless steel grades at companies in USA, Europe, and Asia.
\end{abstract}

Keywords: Steel, reheating, oxyfuel, energy, emission

\section{INTRODUCTION}

As the challenges of massive and increasing use of energy and industrial pollution grow into one of the biggest issues of our time, the modernization of industrial heating systems becomes increasingly important and the centre of attention. One of the known methods to meet this problem is to modify the combustion system by using oxygen instead of air as the primary oxidizer. This technology, called oxyfuel combustion, has been extensively investigated and occasionally employed in industry. In general, it has the potential to substantially decrease both energy use and emissions. If we would fully implement already existing oxyfuel technologies in the steel industry, this industry sector's total $\mathrm{CO}_{2}$ emissions use would be decreased by more than 100 million tonnes annually.

Linde's experience from converting reheating furnaces into all oxyfuel operation shows energy savings ranging from $20 \%$ to $60 \%$. It should be noted that the total energy saving is greater than what could be read on the meter at the furnace, the energy needed to bring the natural gas, for example, to its use in the furnace is of course also saved. In the mid-1980s Linde began to equip the first furnaces with oxygen-enrichment systems. These systems increased the oxygen content of the combustion air to $23-24 \%$. The results were encouraging, 
fuel consumption was reduced and the output, in terms of tonnes per hour, increased. In 1990 Linde converted the first furnace to operation with $100 \%$ oxygen, that is, full oxyfuel combustion, at Timken in USA.

In an air-fuel burner the burner flame contains nitrogen from the combustion air. A significant amount of the fuel energy is used to heat up this nitrogen. The hot nitrogen leaves with the flue-gases and subsequently through the stack, creating energy losses. When avoiding the nitrogen ballast, using industrial grade oxygen, then not only is the combustion itself is more efficient but also the heat transfer; the radiative heat transfer increases massively.

Accordingly, oxyfuel combustion influences the combustion process in several ways. The first obvious result is the increase in thermal efficiency due to the reduced exhaust gas volume, a result that is fundamental and valid for all types of oxyfuel burners. Additionally, the concentration of the highly radiating products of combustion, $\mathrm{CO}_{2}$ and $\mathrm{H}_{2} \mathrm{O}$, is increased in the furnace atmosphere. For melting and heating furnace operations these two factors lead to a higher melt or heating rate, fuel savings, lower $\mathrm{CO}_{2}$ emissions and - if the fuel contains sulphur - lower $\mathrm{SO}_{2}$ emissions, Today's best air-fuel solutions need at least $1.3 \mathrm{GJ}$ for heating a tonne of steel to the right temperature for rolling or forging. With oxyfuel the comparable figure is below $1 \mathrm{GJ}$, a saving of $25 \%$. For continuous heating operations it is also possible to economically operate the furnace at a higher temperature at the entry (loading) side of the furnace. This will even further increase the possible throughput in any furnace unit. Oxyfuel combustion allows all installation pipes and flow trains to be compact without any need for recuperative or regenerative heat recovery solutions. Combustion air-blowers, requiring electricity, and related low frequency noise problems are avoided.

Use of oxyfuel combustion instead of air-fuel does not only lead reduced $\mathrm{CO}_{2}$ emissions, but also to substantially lower off-gas volumes to handle. Additionally, the $\mathrm{CO}_{2}$ concentration in the off-gas is high, which makes it suitable for further processing if wanted.

For steel reheating, two features of the oxyfuel combustion process need to be addressed: the increase in flame temperature and the subsequent potential of thermal NOx forming. The answer to this was Flameless Oxyfuel. Since 2003, therefore, focus has been on using Flameless Oxyfuel, hitherto resulting in 112 successful installations, 90 of these operating fully with $100 \%$ Flameless Oxyfuel. This paper describes results from these installations, which include fuel savings of up to $60 \%$, increased throughput by up to $50 \%$, substantial reductions of $\mathrm{CO}_{2}$ and $\mathrm{NOx}$ emissions, much improved temperature uniformity of the heated steel, reduction of scale losses by up to $50 \%$. The purpose here is to more in detail describe these results.

Table 1 Comparison of energy required to reheat a tonne of carbon steel using different combustion technologies. REBOX ${ }^{\circledR}$ is Linde's trademark for oxyfuel solutions in reheating and annealing.

\begin{tabular}{|c|c|c|c|c|}
\hline & & Air-fuel & $\begin{array}{c}\text { Air-fuel with } \\
\text { recuperator }\end{array}$ & REBOX® oxyfuel \\
\hline Enthalpy in steel & $\mathrm{kWh} / \mathrm{t}$ & 200 & 200 & 200 \\
\hline Transmission losses & $\mathrm{kWh} / \mathrm{t}$ & 10 & 10 & 10 \\
\hline Flue-gas enthalpy & $\mathrm{kWh/t}$ & 299 & $155^{*}$ & 50 \\
\hline $\begin{array}{c}\text { Flue-gas } \\
\text { temperature }\end{array}$ & ${ }^{\circ} \mathrm{C}$ & 1,200 & 850 & 1,200 \\
\hline Air preheating & ${ }^{\circ} \mathrm{C}$ & 20 & 450 & 20 \\
\hline Thermal efficiency & $\%$ & 42 & 60 & 80 \\
\hline Energy need & $\mathrm{kWh} / \mathbf{t}$ & $\mathbf{5 0 0}$ & $\mathbf{3 6 5}$ & $\mathbf{2 6 0}$ \\
\hline Energy need & $\mathrm{GJ} / \mathrm{t}$ & $\mathbf{1 . 8}$ & $\mathbf{1 . 3}$ & 0.94 \\
\hline Oxygen production & $\mathrm{kW/t}$ & & & 25 \\
\hline
\end{tabular}

*after recuperation 


\section{FLAMELESS OXYFUEL TECHNOLOGY}

Increasingly stricter legislation on emissions led to the development of Flameless Oxyfuel. It was for the first time introduced in 2003 by Linde's installations at Outokumpu in continuous furnaces for strip annealing and slabs reheating, respectively. The expression 'flameless combustion' communicates the visual aspect of the combustion type, that is, the flame is no longer seen or easily detectable by the human eye. Another description might be that the combustion is extended in time and space - it is spread out in large volumes; therefore, it is sometimes referred to as "volume combustion". Such a flame has a uniform and lower temperature, practically same temperature as air-fuel combustion, yet containing the same amount of energy [1].

In Flameless Oxyfuel the mixture of fuel and oxidant reacts uniformly through the flame volume, with the rate controlled by partial pressures of reactants and their temperature. Fundamentally here, using burners or lances or a combination of the two, is the matter of utilising velocity in a beneficial way when at same time separating the injection points of the fuel and the oxidant, leaving the traditional design of a burner. In Flameless Oxyfuel, the combustion gases are effectively dispersed throughout the furnace, ensuring more effective and uniform heating of materials even with a limited number of burners installed. Although the first installations took place in reheating and annealing, flameless oxyfuel was quickly adopted for preheating of ladles and converters where it has demonstrated great results as well. The next area being exploited, with substantial positive impact, could be the blast furnace hot stoves. Also, the use of low calorific fuels has been emphasized lately, for example, using blast furnace top gas; use of oxyfuel strongly supports a successful use of low calorific gases.
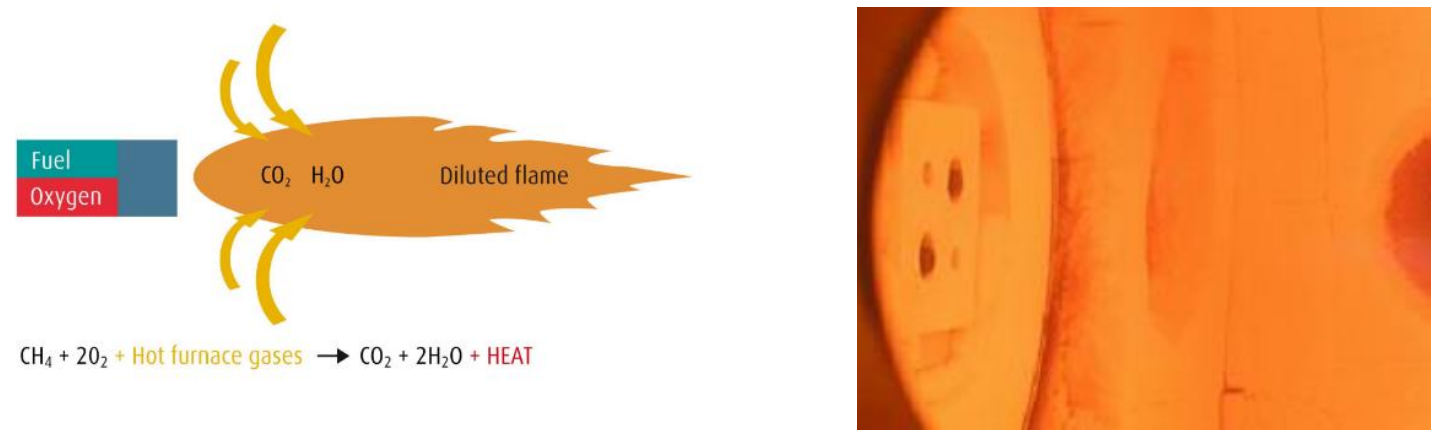

Figure 1 Flameless Oxyfuel combustion - the flame is diluted by hot furnace gases and not detectable by the human eye

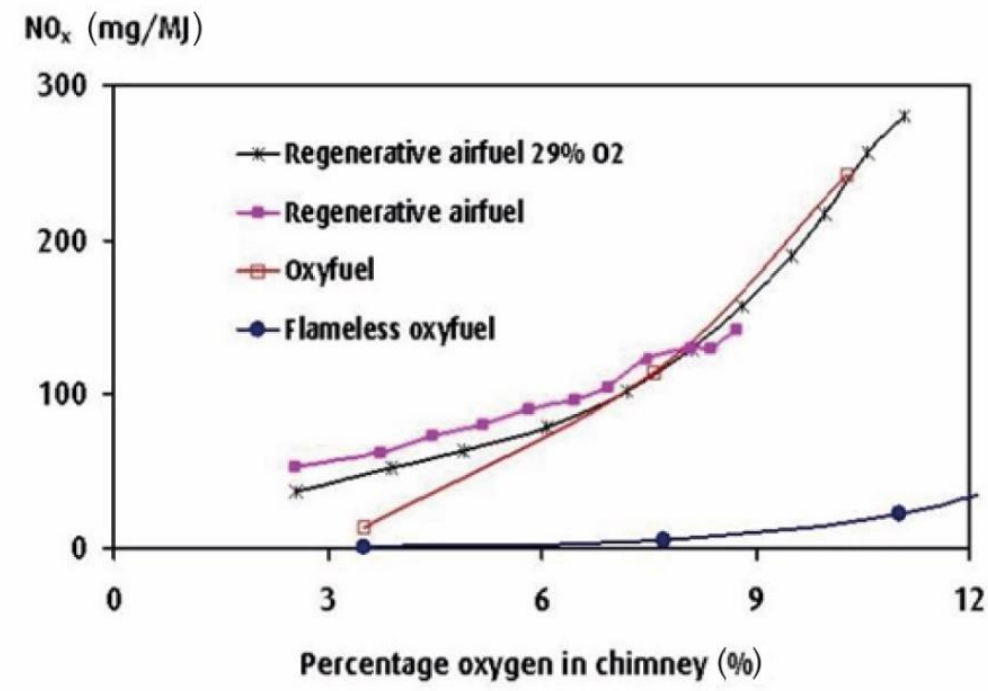

Figure 2 Results from tests with impact on NOx by in-leakage of air into a combustion chamber using different burner technologies [1] 
The lower flame temperature substantially reduces the NOx formation. Low NOx emissions are also important from a global warming perspective; $\mathrm{NO}_{2}$ has a so-called global warming potential 300 times that of $\mathrm{CO}_{2}$. Flameless Oxyfuel has also demonstrated a low sensitivity to air ingress creating NOx formation, which is very important in practical operation. [1]

\section{INSTALLATIONS OF FULL FLAMELESS OXYFUEL IN REHEATING AND ANNEALING}

Converting a steel reheating furnace completely into full Flameless Oxyfuel combustion is a rather big task, particularly if it is a large continuous furnace. Therefore, most of such conversions has taken place in batch furnaces, e.g., soaking pit and chamber furnaces. Among prominent users could be mentioned several producers of engineering steel grades, like bearing steel, including Ascometal (France), Mahindra Sanyo (Indian subsidiary of the Japanese company Sanyo) and Ovako (Sweden). But there are also many successful examples of installations in continuous furnaces like Rotary Hearths and Walking Hearths at, e.g., ArcelorMittal (USA) and Sandvik (Sweden). Those include final products like seamless pipes and rock drills. Other examples are found in continuous annealing of stainless steel, e.g., for production of wire rods at Yongxing and Dongbei Steel in China and strips at Outokumpu in Sweden.

At Ascometal and Ovako the installations in soaking pit furnaces have led to huge fuel savings and productivity increases with over $50 \%$ reduction of the fuel consumption and a $50 \%$ reduction of the total heating and soaking time. Additionally, a more uniform heating has been achieved and also substantial reductions in scale losses. Ascometal has utilised the shorter time to reduce the number of furnaces required to achieve an unchanged output. Ovako was an early adopter of oxyfuel, and today all their furnaces have been converted a second time to now use Flameless Oxyfuel. This has made it possible to compare the differences between these two technologies; Figure 3 shows such a comparison.

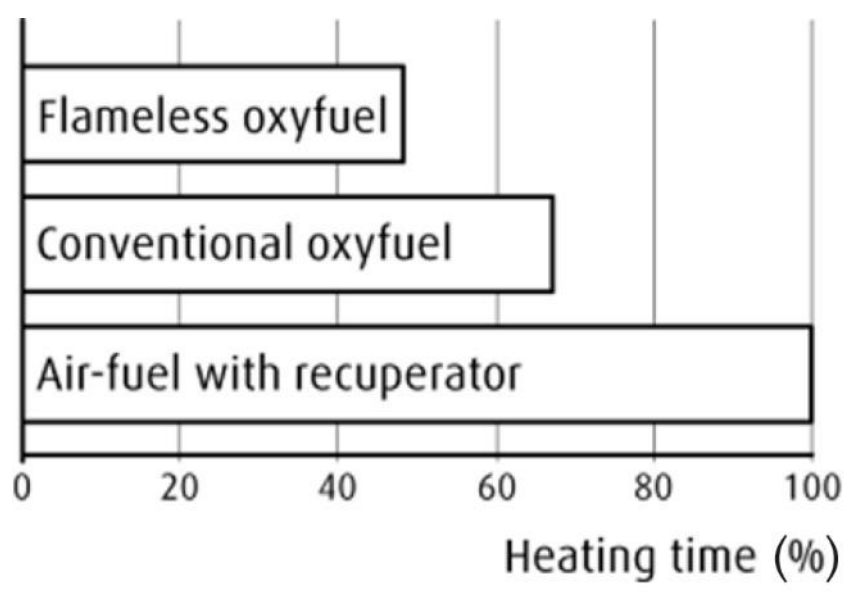

Figure 3 Impact on heating time for use of different combustion technologies at Ovako, Sweden, in same furnaces and for same steel grades. The installed power is smallest in the Flameless Oxyfuel case and highest in the air-fuel case

Extremely good results have been achieved in Rotary Hearth Furnaces, e.g., at Arcelor Mittal and MST in the USA with fuel savings above $60 \%$. At the seamless tube producer ArcelorMittal Shelby in Ohio, a 15-metre diameter rotary hearth furnace was fully converted into Flameless Oxyfuel. The former air-fuel fired furnace was converted in two steps, first using oxygen-enrichment for a period of time and then implementation of the full Flameless Oxyfuel operation. Excellent results were achieved, including $25 \%$ more throughput, $60 \%$ fuel savings, $\mathrm{CO}_{2}$ emissions that dropped accordingly, $\mathrm{NOx}$ emission $<70 \mathrm{mg} / \mathrm{MJ}$ corresponding to $92 \%$ less on an annual basis, and $50 \%$ reduced scale losses. ArcelorMittal has received the Association for Iron \& Steel Technology's Energy Achievement Award for this installation. 

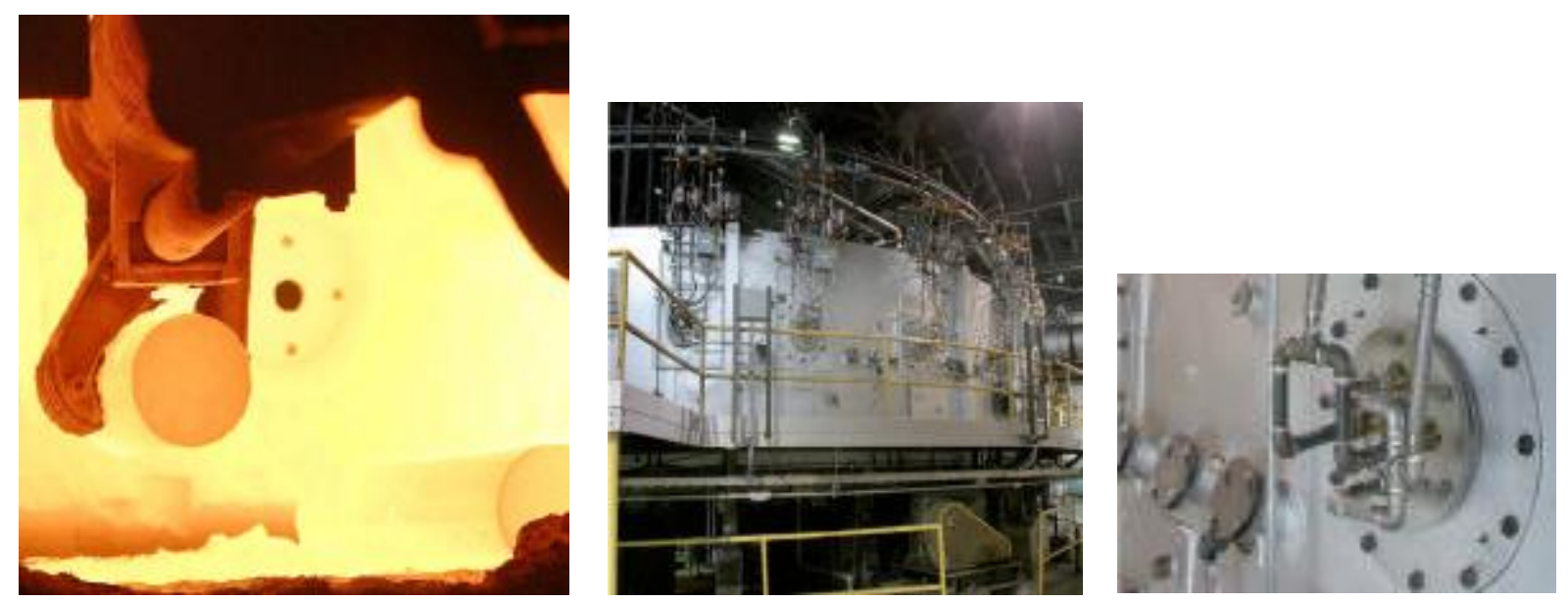

Figure $4 \mathrm{~A}$ look through the furnace door and outside views of the Full Flameless Oxyfuel installation in a Rotary Hearth Furnace at ArcelorMittal Shelby, USA. Please note that the burner is firing straight towards the viewer, however, with a flame that is not visible. The photograph to the right shows the backside of the mounted Full Flameless Oxyfuel burner, with a start-burner in the middle for heating up a cold furnace and inlets to the lances for injection of fuel and oxygen for the Flameless operation.

Dongbei Special Steel Group at Dalian, China, uses Full Flameless Oxyfuel for a $70 \mathrm{t} / \mathrm{h}$ continuous annealing of stainless steel wire rod, so-called Direct Solution Treatment (DST). The fuel used is gasified coal with a calorific value at $2 \mathrm{kWh} / \mathrm{m}^{3}$. Another such DST installation is found at the company Yongxing, also in China. Here the fuel is natural gas. This $60 \mathrm{t} / \mathrm{h}$ production, is the most energy efficient stainless wire rod annealing line in the world, with a total fuel consumption including idling time, etc., at $<70 \mathrm{kWh} / \mathrm{t}$.

Sandvik is another company using fully converted continuous reheating for its production in Sweden, and as well with excellent results. It is highly interesting to note, that Sandvik's operations include production of very high alloyed materials, e.g., for rock drills. This clearly demonstrates that Flameless Oxyfuel has no negative impact when heating even very high alloyed steel grades. Additionally, Sandvik uses Full Flameless Oxyfuel also in batch furnaces.
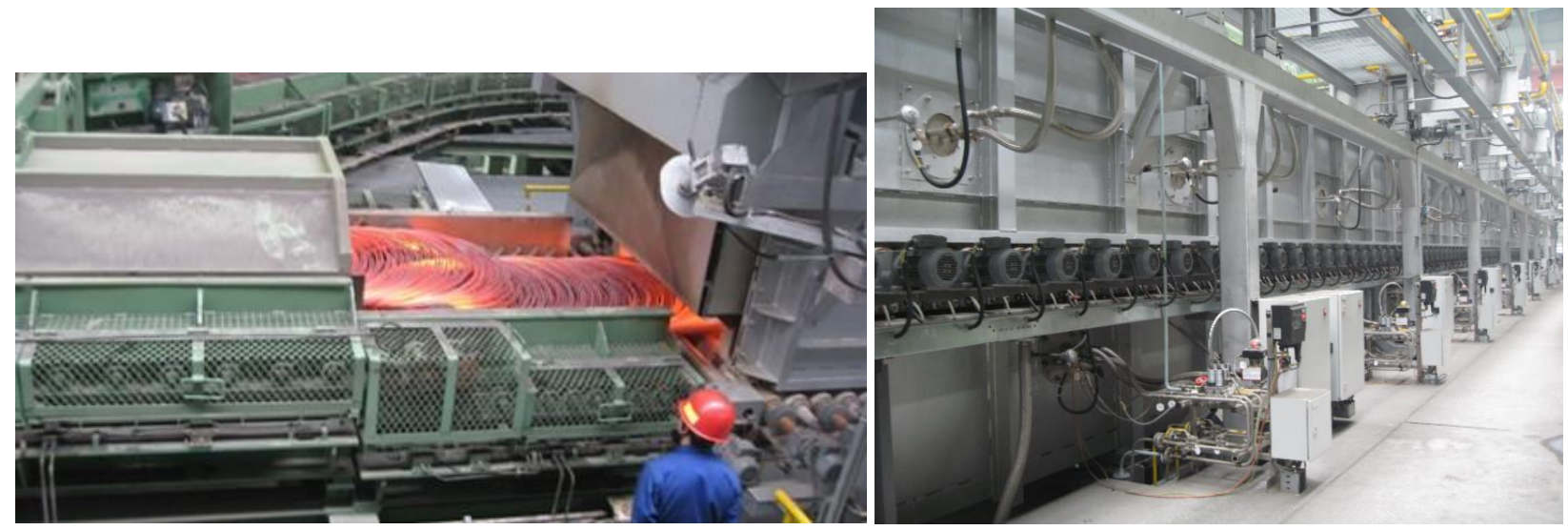

Figure $5100 \%$ Full Flameless Oxyfuel fired Roller Hearth Furnace for annealing of stainless steel wire rod at Yongxing, China, the world's most energy efficiency such annealing. Natural gas fired Full Flameless Oxyfuel burners are mounted and operated both above and beneath the pass-line in all zones of the furnace.

\section{USE OF SEMI FLAMELESS OXYFUEL IN REHEATING}

As discussed, converting large continuous steel reheating furnaces into Full Flameless Oxyfuel is a big undertaking. Moreover, at many plants there is not several furnaces operating in parallel, so such a retrofit 
might require a stoppage of the whole production for a month or so. Also, when converting a, say, $300 \mathrm{t} / \mathrm{h}$ Walking Beam Furnace into Full Flameless Oxyfuel, the oxygen requirement could be $500 \mathrm{t} / \mathrm{d}$, which normally is not available without investments. Additionally, the "efficiency" of the percentage of the oxygen use when going from $21 \%$ (air) to $100 \%$ (full oxyfuel), show diminishing returns; we can find a "sweet spot" somewhere at $40-60 \%$. If we reduce the amount of air in an air-fuel system and instead inject oxygen with high velocity, we can then also achieve a semi flameless combustion. It has been found, that reducing the air-flow and compensate for it with high velocity oxygen injection so the resulting combustion takes place with around $50 \%$ oxygen, is a very good operating point.

This will create a Semi Flameless Oxyfuel, which, accordingly, can be established without replacing the existing air-fuel burners. By reducing the air flow and substituting high velocity oxygen injection into the combustion space, great benefits can be achieved. About $75 \%$ of the oxygen needed for the combustion is then supplied with this technique. The flue-gas volume is less than $45 \%$ that of air-fuel.

The installation is comparatively uncomplicated as it does not include any replacement of burners or installation of additional burners, which minimises the installation downtime; practically the installation work is usually done without requiring any additional furnace stoppages. Moreover, the system start-up normally would take about only one day.

The air-fuel system can at any time be brought back into operation as it was before; the oxygen system is an add-on that can be turned on and off. This eliminates any potential risk relating to the implementation, and it enables operation to be flexible and optimised in response to fluctuating fuel cost and production requirements. Some important general results include:

- $\quad$ No negative impact on the surface quality;

- A positive impact on the temperature uniformity of the steel;

- $\quad$ The ideal heating curve suggested by the control system can be achieved more easily;

- $\quad$ Less smoke emanating from the furnace, greatly improving the plant environment;

- A reduction of $\mathrm{NO}$ x emission by $45 \%$ can be achieved;

- Fuel consumption can be decreased by $25 \%$, leading to the same reductions in $\mathrm{SO}_{2}$ and $\mathrm{CO}_{2}$ emissions;

- $\quad$ Production throughput can be increased by up to $30 \%$.

When retrofitting a furnace, the existing air-fuel system is kept. The oxygen system would be an add-on, which can be switched on and off as per demands and with a response time of about one minute. Naturally, the full advantages of Flameless Oxyfuel cannot be captured, however, yet excellent results have been achieved in more than a dozen of furnaces in Europe and Asia. The first installations took place at SSAB and Outokumpu in Sweden and Finland, respectively, but lately most installations have been in Asia. Outokumpu Tornio Works is one of the leading stainless steel plants in the world, using a fuel that is a mixture of liquefied propane gas and $\mathrm{CO}$ gas from the ferrochrome production furnaces on site. With Semi Flameless Oxyfuel in the reheating, the heating capacity of each furnace was increased from 250 to $>300 \mathrm{t} / \mathrm{h}$ and at the same time specific fuel consumption was reduced by $30 \mathrm{kWh} / \mathrm{ton}$.

Very interesting results have been achieved at Masteel in China, where this type of Semi Flameless Oxyfuel has been installed in a $300 \mathrm{t} / \mathrm{h}$ Walking Beam Furnace at a hot strip mill. As this is one out of three identical furnaces there, comparisons can be made. Despite only being applied in one heating zone, the following results have been reported:

- $\quad$ throughput capacity $+20 \%$,

- fuel consumption $-20 \%$,

- NOx emissions $-20 \%$,

- $\quad$ scale losses $-20 \%$. 


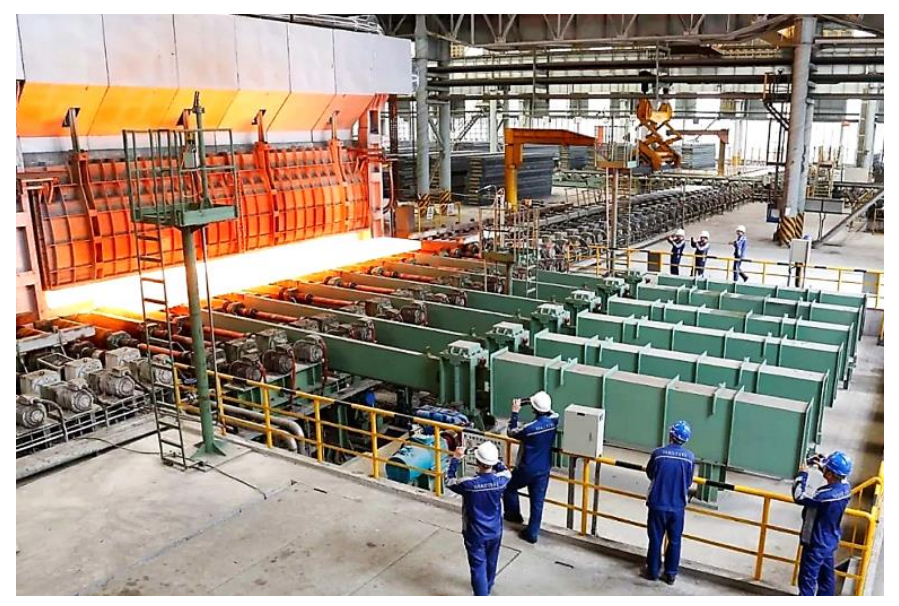

Figure $7 \mathrm{~A}$ proud moment at Masteel when the first slab is discharged from the $300 \mathrm{t} / \mathrm{h}$ Walking Beam Furnace retrofitted with Semi Flameless Oxyfuel

Results of practical measurements of the scale losses are shown in Figure 8. Additionally, Masteel has evaluated the forces required to be applied in the downstream rolling mill. It was found, that about $5 \%$ less rolling force was required for steel that had been heated with Semi Flameless Oxyfuel - this has been investigated and confirmed for various steel grades - and it also led to much less fluctuation of forces applied across the slab during rolling. Accordingly, a clearly more uniform heating had been achieved. This is further illustrated in Figure 9.

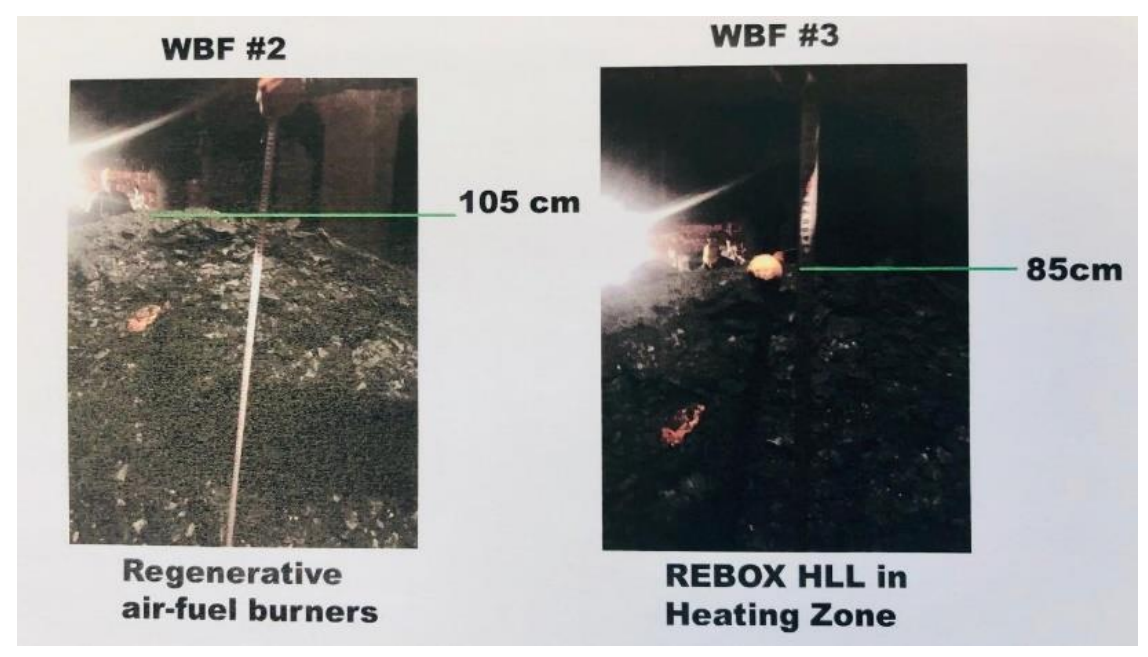

Figure 8 Measurements comparing scale losses generated in two identical Walking Beam Furnaces at Masteel, one operating fully with regenerative air-fuel and the other using Semi Flameless Oxyfuel in the heating zone

Siam Yamato Steel (SYS) in Thailand is operating with Semi Flameless Oxyfuel in a $100 \mathrm{t} / \mathrm{h}$ Walking Beam Furnace. Here it has been possible to reduce the fuel consumption by up to $30 \%$, the highest reported figure for use of this technology in steel reheating.

\section{OUTLOOK}

It is interesting to note the flexibility that can be achieved when using Flameless Oxyfuel. One aspect of the potential to increase throughput is, when having multiple furnaces in parallel, to operate with less number of 
furnaces for unchanged total production. At one of the plants of Ascometal, for example, after the conversion nine soaking pit furnaces are producing same output as was earlier done in 13 furnaces.

Another possibility could be to combine air-fuel, Semi Flameless Oxyfuel and Full Flameless Oxyfuel and use it dependent on needs. At Kalyani Carpenter in India, we find a good example of this, where they have a 30 $\mathrm{t} / \mathrm{h}$ rated Walking Beam Furnace. Dependent on the cross-section sizes of the blooms to be heated, they have different demands in terms of tonnes per hour to keep the same pace in the downstream rolling mill. Based on that Kalyani Carpenter went for the following solution, where they can run in three modes:

- $\quad 30-32 \mathrm{t} / \mathrm{h}$ : air-fuel

- $\quad 34-37 \mathrm{t} / \mathrm{h}$ : Semi Flameless Oxyfuel

- $\quad 38-42 \mathrm{t} / \mathrm{h}$ : Semi Flameless Oxyfuel + Full Flameless Oxyfuel in the Preheating Zone

There are several developments and trends in the field of use of Flameless Oxyfuel. For example, separating the fuel and the oxygen further is one of them, with on and off injection of fuel from one side of a furnace and oxygen from the opposite side. This has already been applied in the glass industry. Another way could be to run roof burners substantially sub-stoichiometric and inject oxygen through high velocity lances placed laterally.

In general, there is the possibility to view the whole furnace as a flameless "flame chamber" where a large part of the energy for material heated provided from wall radiation. This can be maintained by multiple injection points, some injecting fuel and some injection oxygen. High velocity injection is of course a key then to achieve a flameless regime and a good mixing.

A very interesting opportunity when using Flameless Oxyfuel in continuous steel reheating is to run at different stoichiometry levels in different zones. For example, with sub-stoichiometric combustion in the soaking part and over-stoichiometric in the heating part. This could be a way both to reduce NOx emissions to even lower levels and to further reduce scale losses. We are likely to see the first such operation soon, driven by demands for additional reduction of scale losses.

Using oxyfuel and particularly Flameless Oxyfuel strongly supports an increased use of low calorific fuels of different kinds; for example: a blast furnace top gas combusted with oxyfuel provides same heating conditions as natural gas combusted with air-fuel. At an integrated steel mill this could mean using a mix gas with a lower calorific value in the reheating furnaces and thereby freeing up for an increased generation of electricity.

Flameless Oxyfuel using hydrogen as a fuel might soon be available. Linde has made tests with full hydrogenoxygen combustion heating of steel of different grades, and the results are encouraging.

\section{CONCLUSIONS}

Since 2003, Flameless Oxyfuel has proven great results in numerous installations in the steel and metals industries, both for melting and heating operations. That includes use of both fully flameless and semi flameless installations, and combinations of the two.

Flameless Oxyfuel combustion has major advantages over conventional oxyfuel and, even more, over any kind of air-fuel combustion. Oxyfuel gives an overall thermal efficiency in the heating of $80 \%$, air-fuel reaches 40-60\%. With Flameless Oxyfuel, compared air-fuel, the installations show energy savings in reheating furnaces of at least $25 \%$, but many times $50 \%$ or even more.

The results include not only fuel savings and, thereby, reduced $\mathrm{CO}_{2}$ emissions, but also considerable material yield increases, largely improved heating uniformity, and reduced NOx emissions. The improved heating uniformity also leads to time-savings in steel reheating. As NOx formation is depending on temperature, flameless combustion means ultra-low NOx emissions. This is important in all operations, but an important feature of Flameless Oxyfuel is its insensitivity to in-leakage of air, where it yet delivers extremely low NOx 
emission levels. In continuous furnaces operations with Flameless Oxyfuel, NOx values below $80 \mathrm{mg} / \mathrm{m}^{3}$ (at 8 $\%$ oxygen) have been achieved. It is important to note, that as this is measured as $\mathrm{mg} / \mathrm{m}^{3}$ but with flue-gas volumes $70 \%$ lower than for air-fuel combustion - the real emission is ultralow!

If all reheating and annealing furnaces would employ oxyfuel combustion, the $\mathrm{CO}_{2}$ emissions from the world's steel industry would be reduced by more than 100 million tonnes per annum. Additionally, a small off-gas volume and a high concentration of $\mathrm{CO}_{2}$ make it increasingly suitable for Carbon Capture and Sequestration.

By retrofitting an existing reheat furnace into Flameless Oxyfuel, it has been shown the throughput can be increased by $20-60 \%$. This creates also production flexibility and could even lead to that two furnaces could produce same volume as was earlier done in three furnaces.

Semi Flameless Oxyfuel can be installed in existing furnaces as an 'add-on", also including configurations using regenerative burners. The installations show increased throughput capacity by $20-30 \%$ and reduce fuel consumption by $20-25 \%$.

Today there are more than 110 furnaces in the steel industry across the world that use Full Flameless or Semi Flameless Oxyfuel combustion successfully. These are great examples showing how the steel industry can produce more in existing equipment and at same time reduce fuel consumption and emissions in a costefficient way when fulfilling a stricter environmental legislation, contributing to making our world more productive.

\section{REFERENCES}

[1] NAKKHONG, C., TANGPRASOPCHOT, N., TANANIRAN, P., DOIJAD, G. Successful Results from Improved Sustainability by Using Flameless Oxyfuel in SYS. In: Annual Meeting \& Conference of South East Asia Iron and Steel Institute (SEASI). Bangkok: Thailand, 2019. 